\title{
Peran Guru Kelas dalam Pembentukan Karakter Disiplin pada
}

\section{Siswa}

\author{
Yayuk Setyaningrum¹, Rahmat Rais², Eka Sari Setianingsih ${ }^{3}$ iD \\ 1,2,3 Program Studi Pendidikan Guru Sekolah Dasar, Universitas PGRI Semarang, Indonesia \\ *Corresponding author: : setyaningrumy0198@gmail.com
}

\begin{abstract}
Abstrak
Rendahnya kemampuan karakter disiplin siswa kelas V SD diduga karena kurangnya perhatian kepada siswa. Teknik yang digunakan dalam pembentukan karakter adalah peran guru kelas lebih ditekankan lagi. Tujuan Penelitian ini bertujuan untuk mengetahui bagaimana peran guru kelas dalam pembentukan karakter disiplin pada siswa kelas V SD. Jenis penelitian ini adalah penelitian kualitatif dalam bentuk studi kasus. Subjek penelitian ini adalah guru kelas V, siswa kelas V, serta kepala sekolah. Objek dari penelitian ini adalah pembentukan karakter disiplin pada siswa. Data dari penelitian ini diperoleh melalui observasi, wawancara, studi dokumentasi, dan angket. Hasil dari penelitian menunjukkan bahwa guru kelas sangat berperan (menentukan) dalam pembentukan karakter disiplin pada siswa dengan menggunakan tiga teknik yaitu; teknik inner control yaitu keteladanan dalam segala aspek kehidupan sekolah sebagaimana dituangkan dalam peraturan sekolah, teknik external control yaitu menegakkan peraturan sekolah dengan dua cara, memberikan hukuman yang bersifat mendidik kepada siswa yg melanggar peraturan (tidak disiplin) dan memberi pujian/hadiah/respon positif bagi siswa yang disiplin (tidak melanggar peraturan), teknik cooperatif control yaitu mengadakan kerjasama yang di wujudkan dalam bentuk kontrak kerja yang berisi peraturan disiplin sekolah berupa tata tertib dan sanksinya bagi yang melanggarnya.
\end{abstract}

Kata kunci: Karakter, Disiplin,

\section{Abstract}

The low ability of the disciplinary character of grade $v$ elementary school students is thought to be due to a lack of attention to students. the technique used in character building is that the role of the classroom teacher is emphasized again. The purpose of this study was to determine how the role of classroom teachers in shaping the character of discipline in grade $v$ Elementary school students. This type of research is qualitative research in the form of case studies. the subjects of this study were teachers in grade $v$, students in grade $v$, and school principals. The object of this research is the formation of disciplinary character in students. The data from this study were obtained through observation, interviews, documentation study, and questionnaires. The results of the study indicate that the classroom teacher plays a very important role (determines) in the formation of disciplinary character in students by using three techniques, namely; inner control techniques, exemplary in all aspects of school life as outlined in school regulations, external control techniques, enforcing school rules in two ways, giving educational penalties to students who violate the rules (not disciplined) and giving praise / gifts / positive responses to disciplined students (do not violate the rules), cooperative control techniques, namely holding cooperation which is manifested in the form of a work contract containing school discipline rules in the form of rules and sanctions for those who break them..

Keywords: Character, Discipline

\section{Introduction}

Karakter adalah keseluruhan nilai-nilai, pemikiran, perkataan, dan perilaku atau perbuatan yang telah membentuk diri seseorang, karakter lebih kepada sifat, watak, tabiat, budi pekerti atau akhlak yang dimiliki oleh seseorang yang merupakan ciri khas yang dapat membedakan perilaku, tindakan dan perbuatan antara yang satu dengan yang lain (Abdullah et al., 2015; Basri \& Dwiningrum, 2020; Choli, 2019). Nilai-Nilai karakter ada sebanyak 18 nilai karakter, yaitu : religius, jujur, toleransi, disiplin, kerja keras, kreatif, mandiri,

$\begin{array}{lll}\text { History: } & & \text { Publisher: Undiksha Press } \\ \text { Received } & : 24 \text { August } 2020 & \text { Licensed: This work is licensed under } \\ \text { Revised } & : 1 \text { September } 2020 & \text { a Creative Commons Attribution 3.0 License } \\ \text { Accepted } & : 26 \text { September } 2020 & \text { C }\end{array}$


demokratis, rasa ingin tahu, semangat kebangsaan, cinta tanah air, menghargai prestasi, bersahabat/komunikatif, cinta damai, gemar membaca, peduli lingkungan, peduli sosial, tanggung jawab (Adibatin, 2016; Nasution, 2017; Sutiyono, 2013). Salah satu karakter yang menentukan kesuksesan seseoarang adalah disiplin. Disiplin adalah kesadaran dan kesediaan anak menaati semua peraturan dan norma sosial yang berlaku (Abu, 2014; Buntarti \& Udjang, 2015; Machfiroh et al., 2019).

Perilaku disiplin dalam belajar masih ada yang aturan yang belum ditaati oleh siswa, siswa tidak memakai seragam dengan lengkap dan benar, tidak melaksanakan piket yang merupakan kewajiban bagi setiap siswa contoh lain yang menunjukan kurangnya sikap disiplin dalam diri siswa yaitu ketika pembelajaran dikelas (Malik \& Afandi, 2020). Beberapa penyebab perilaku peserta didik yang indisiplin, sebagai berikut: Pertama, Perilaku tidak disiplin bisa disebabkan oleh guru. Kedua, Perilaku tidak disiplin bisa disebabkan oleh sekolah; kondisi sekolah yang kurang menyenangkan, kurang teratur, dan lain-lain dapat menyebabkan perilaku yang kurang atau tidak disiplin. Ketiga, Perilaku tidak disiplin bisa disebabkan oleh peserta didik, peserta didik yang berasal dari keluarga yang broken home. Keempat, Perilaku tidak disiplin bisa disebabkan oleh kurikulum, kurikulum yang kurang fleksibel, terlalu dipaksakan dan lain-lain bisa menimbulkan perilaku yang tidak disiplin, dalam proses belajar mengajar pada khususnya dan dalam proses pendidikan pada umumnya (Wuryandani et al., 2014). Mendisplinkan peserta didik adalah tindakan merubah kebiasaan lama yang sifatnya kurang baik menuju pada kebiasaan baru yang lebih baik. Hal ini bukanlah pekerjaan yang mudah tetapi membutuhkan kerja keras. Sulit bukan berarti tidak bisa dirubah, melainkan harus berani untuk memulai menjadi kebiasaan baik. Memulai kebiasaan baik harus dibarengi dengan niat baik dan kuat supaya menghasilkan hasil yang lebih maksimal. Mendisplinkan peserta didik bukan berteori tetapi membuktikan teori. Guru yang selalu memberikan tugas dan membantu peserta didik yang tidak mampu, selalu memilih kata-kata yang mudah dicerna dan dimengerti, maupun memberikan solusi terhadap kesulitan belajar anak di sekolah adalah tindakan tindakan mendisplinkan peserta didik.

Berdasarkan pengamatan saat berada di SD Negeri Tegalontar 03 Kabupaten Pekalongan adalah ketika peserta didik sudah mulai melakukan kedisiplinan yang bagus di lingkungan sekolah maupun di dalam kelas saat pembelajaran. Terlihat saat peserta didik hadir di sekolah tepat waktu, menjaga kebersihan lingkungan sekolah, tertib melaksanakan upacara, tertib memakai seragam sekolah dan tertib dalam melaksanakan ibadah. Begitupun kedisiplinan peserta didik juga sudah terbentuk saat berada didalam kelas seperti menyiapkan buku pelajaran sebelum pelajaran dimulai, memperhatikan guru saat menerangkan pembelajaran, mengerjakan dan mengumpulkan PR tepat waktu, menjaga kebersihan kelas, tertib dalam melakukan piket kelas dan tertib membuang sampah pada tempatnya. Terbentuknya kedisiplinan tersebut karena adanya peran guru di sekolah yang selalu memberi nasihat dan memberi contoh kepada peserta didiknya untuk melakukan kegiatan disiplin. Guru yang menunjukkan kebiasaan baik dalam hidupnya adalah contoh disiplin yang baik. Mendisiplinkan peserta didik tidak cukup hanya diajak tetapi seharusnya ditindakkan. Peraturan dan tata tertib sekolah akan lebih baik apabila peserta didik dan guru melaksanakanya dengan ikhlas dan penuh tanggungjawab. Agar seorang guru dalam kegiatan pembelajaran bisa menyelenggarakan pendidikan secara optimal dan profesional maka seorang guru memerlukan pengetahuan yang dasar dan menyeluruh tentang proses kegiatan pembelajaran serta langka-langkah yang harus diambil untuk mewujudkan suatu pembelajaran yang berkualitas, sehingga tugas sebagai seorang guru dilaksanakan dengan baik dan tentu saja tujuan dari pembelajaran tersebut juga bisa terpenuhi. Sehubungan dengan hal tersebut, banyaknya perilaku peserta didik yang keluar dari norma dan aturan yang berlaku, peserta didik yang tidak bisa menghargai orang yang lebih dewasa, serta perilaku peserta didik yang tidak dapat menaati aturan dan tata tertib sekolah merupakan 
tugas dari seorang guru sebagai pendidik. Salah satu faktor terjadinya hal tersebut karena kurangnya karakter disiplin yang diterapkan peserta didik di dalam dan di luar pembelajaran sekolah, ketika di dalam sekolah peserta didik biasanya melakukan kerja kelompok bersama teman-temannya namun banyak diantara mereka yang masih tidak bisa bekerja kelompok dengan baik, namun diluar pembelajaran sikap disiplin peserta didik ini sangat kurang sekali seperti banyaknya perkelahian, saling adu domba dan sebagainya. Disinilah peran guru dalam membentuk karakter disiplin peserta didik diperlukan.

Hal ini sesuai dengan penelitian yang dilaksanakan oleh Puji Rahayu dan Maisaroh (2008) hasil penelitian dapat ditarik kesimpulan bahwa guru berperan sebagai penyayang, model, dan mentor dalam membentuk karakter siswa. Sebagai penyayang, guru juga berperan sebagai pembimbing dan motivator. Sebagai model, guru juga berperan sebagai inspirator dan teladan, serta sebagai mentor guru juga berperan sebagai inisiator, evaluator, dan motivator. Begitu juga dengan penelitian yang dilaksankan oleh Setyawan et al., (2015). Hasil penilaian menunjukkan bahwa produk SSP dinyatakan layak dengan perincian silabus berkategori baik dengan skor 47, RPP skor 67, bahan ajar skor 65, LKPD skor 47 dan instrumen penilaian yang dikembangkan dinyatakan valid berkategori sangat baik, sedangkan media pembelajaran yang dikembangkan berkategori baik dengan skor 66. Hasil uji coba menunjukkan bahwa SSP yang dikembangkan dinyatakan memenuhi kriteria praktis dilihat dari penilaian guru skor 281 dan respon siswa skor 730. Pada uji coba lapangan didapatkan hasil untuk kelas kontrol rata-rata skor pretest 70,8 dan rata-rata skor posttest 80,8. Sedangkan pada kelas eksperimen memperoleh skor rata-rata pretest 74,1 dan skor posttest 90,9. Peningkatan skor kelas kontrol sebesar 10 dan peningkatan kelas eksperimen sebesar 16,8. Pembelajaran dengan SSP yang dikembangkan mampu membangun karakter disiplin dan kreatif. Rata-rata hasil penilaian afektif siswa untuk karakter disiplin adalah $100 \%$ dan kreatif adalah 94\%. Penelitian yang dilaksanakan oleh Ansori (2020). Hasil penelitian membuktikan bahwa guru berperan penting dalam pembinaan disiplin siswa, sehingga siswa mentaati segala peraturan yang ditetapkan dan mencegah timbulnya problem-problem disiplin.

Tujuan Penelitian ini bertujuan untuk mengetahui bagaimana peran guru kelas dalam pembentukan karakter disiplin pada siswa kelas V SD Tegalontar 03 Kabupaten Pekalongan. Oleh karena itu, untuk melihat tindakan seorang guru dan perannya terhadap kedisiplinan siswa di SD Negeri Tegalontar 03 Kabupaten Pekalongan, adalah melihat kesesuaian tindakan guru dalam menjalankan tugas pokok dan fungsinya, karena pada dasarnya pesertta didik akan meniru apa yang dilakukan oleh gurunya, sehingga perilaku peserta didik sangat dipengaruhi oleh guru yang ada disekolah.

\section{Materials and Methods}

Jenis penelitian yang digunakan dalam penelitian ini adalah penelitian kualitatif studi kasus. John W. Cresswell (tanpa tahun: 323) menjelaskan penelitian studi kasus sebagai berikut. "Case studies are strategy of inquiry in which the researcher explores in depth a program, activity, process, or one or more individuals. Cases are bounded by time and activity, and researchers collect detailed information using a variety of data collection procedures over a sustained period of time." Studi kasus merupakan rancangan penelitian yang ditemukan di banyak bidang khususnya evaluasi, di mana peneliti mengembangkan analisis mendalam atas suatu kasus, sering kali program, peristiwa, aktivitas, proses, atau satu individu atau lebih. Kasus-kasus dibatasi oleh waktu dan aktivitas, dan peneliti mengumpulkan informasi secara lengkap dengan menggunakan berbagai prosedur pengumpulan data berdasarkan waktu yang telah ditentukan. 
Penelitian ini dilaksanakan di SD Negeri Tealontar 03 Kabupaten Pekalongan. Penelitian ini dilaksanakan pada semester ganjil dengan alokasi waktu pada bulan Juli 2020 . Data primer adalah data dasar yang diperoleh dari orang pertama, dari sumber asalnya yang belum diolah atau diuraikan orang lain. Dalam penelitian ini yang menjadi data primer adalah data yang diperoleh dari hasil interview (wawancara), pengamatan (observasi) dan angket dengan objek kepala sekolah, guru kelas V SDN Tegalontar 3 dan beberapa siswa kelas V SDN Tegalontar 3. Data sekunder adalah data yang diperoleh langsung dari pihakpihak yang berkaitan berupa data-data sekolah dan berbagai literatur yang relevan dengan pemahaman, dan data ini diberikan kepada pengumpul data. Misalnya, lewat orang lain, sumber buku, dokumen pribadi, dokumen resmi sekolah, arsip, dan lain-lain. Data ini berguna untuk melengkapi data primer. Data yang dihasilkan dalam penelitian ini diantaranya adalah profil SDN Tegalontar 3, visi, misi dan tujuan, struktur organisasi, data guru dan siswa.

Teknik pengumpulan data yang dilakukan oleh peneliti dalam penelitian ini adalah dengan observasi, wawancara, angket dan studi dokumentasi. Penelitian ini menggunakan peneliti sebagai instrumen utama dan menggunakan alat bantu untuk memperoleh data lapangan yang meliputi pedoman observasi, pedoman wawancara, pedoman angket dan pedoman studi dokumentasi.

Data dianalisis menggunakan langkah-langkah reduksi data, penyajian data, dan penarikan kesimpulan. Dalam penelitian ini, Peneliti menggunakan uji kredibilitas untuk menguji keabsahan data meliputi triangulasi teknik dan triangulasi sumber. Teknik pengumpulan data mengenai pembentukan karakter disiplin pada siswa kelas V SD Negeri Tegalontar 03 yang digunakan dalam penelitian ini yaitu observasi, wawancara, angket dan dokumentasi. Moelong (2012: 330) menyatakan triangulasi sumber untuk menguji kredibilitas data dengan membandingkan dan mengecek data yang telah diperoleh melalui berbagai sumber. Triangulasi teknik untuk menguji kredibilitas data dengan cara mengecek sumber yang sama dengan teknik yang berbeda. Data mengenai pembentukan karakter disiplin pada siswa kelas V SD Negeri Tegalontar 03 diperoleh dari beberapa sumber yaitu kepala sekolah, guru kelas V, dan siswa kelas V. Informasi yang diberikan dari ketiga sumber tersebut tentunya tidak selalu sama persis, sehigga diperlukan adanya pengecekan. Sugiyono (2012: 373) menyatakan bahwa triangulasi sumber untuk menguji kredibilitas data dilakukan dengan cara mengecek data yang telah diperoleh melalui beberapa sumber.

\section{Results and Discussion Hasil penelitian}

Pembentukan karakter disiplin pada siswa kelas V SDN Tegalontar 03 dilakukan melalui teknik exsternal control, teknik inner control dan teknik cooperative control.

\section{Teknik External Control}

Dari hasil penelitian berupa hasil wawancara siswa, guru, kepala sekolah, angket, dan studi dokumentasi didapatkan hasil bahwa meskipun ada siswa yang tidak disiplin dalam kegiatan upacara bendera, namun guru tidak memberikan sanksi maupun hukuman. Selain itu adanya kesadaran pada diri siswa yang tidak disiplin. Guru hanya memberikan peringatan serta arahan maupun teguran saja tanpa memberikan hukuman kepada siswa yang melanggar. Hal tersebut tidak sesuai dengan pendapat (Noor, 2012) yang menyatakan bahwa mendisiplinkan peserta didik dengan teknik External control bisa dilakukan dengan memberikan ancaman serta menakut-nakuti dan ditawari dengan ganjaran. Ancaman diberikan kepada peserta didik yang tidak disiplin, sedangkan ganjaran diberikan kepada peserta didik yang berdisiplin tinggi. 


\section{Teknik Inner Control}

Dari hasil wawancara dengan beberapa siswa, guru dankepala sekolah dapat disimpulkan bahwa guru menanamkan disiplin menggunakan teknik inner control yaitu berupa guru selalu datang tepat waktu kesekolah atau mengajarkan keteladan atau disiplin waktu kepada siswanya. Hal tersebut sesuai dengan pendapat (Noor, 2012), yang menyatakan bahwa mendisiplinkan peserta didik dengan teknik inner control yaitu dengan guru dituntut untuk menjadi teladan bagi peserta didik dalam hal kedisiplinan.

\section{Teknik Cooperative Control}

Berdasarkan hasil penelitian yang di lakukan dapat di simpulkan bahwa, guru melakukan penanaman karakter disiplin dengan membuat kontrak belajar yang dibuat dan disepakati bersama antara guru dengan siswa. Dan siswa harus bisa menaati kontrak belajar yang sudah dibuat tersebut. Hal tersebut sesuai dengan pendapat (Noor, 2012), yang menyatakan bahwa mendisiplinkan peserta didik dengan teknik cooperatif control yaitu dengan guru bersama peserta didik membuat kontrak belajar yang berisi aturan yang harus ditaati bersama.

\section{Pembahasan}

Guru juga menegur dan memberi peringatan kepada siswa agar lebih disiplin lagi dalam pembelajaran di dalam kelas. Selian itu siswa juga diajarkan agar berlatih disiplin dan mematuhi aturandan tata tertib yang berlaku di sekolah. Hal ini sesuai dengan pendapat Noor, (2012), yang menyatakan bahwa mendisiplinkan peserta didik dengan teknik external control bisa dilakukan denganmemberikan ancaman serta menakut-nakuti dan ditawari dengan ganjaran. Ancaman diberikan kepada peserta didik yang tidak disiplin, sedangkan ganjaran diberikan kepada peserta didik yang berdisiplin tinggi. Terbukti dengan siswa yang selalu taat dan disiplin terhadap aturan yang sudah ditetapkan oleh sekolah. Dan jika ada siswa yang tidak memakai seragam sesuai dengan jadwal yang sudah ditentukan baik kepala sekolah maupun guru memberikan teguran. Selain itu para siswa juga selalu memakai sepatu bila ke sekolah. Hal ini tidak sesuai dengan pendapat (Noor, 2012), yang menyatakan bahwa mendisiplinkan peserta didik dengan teknik external control bisa dilakukan dengan memberikan ancaman serta menakut-nakuti dan ditawari dengan ganjaran. Ancaman diberikan kepada peserta didik yang tidak disiplin, sedangkan ganjaran diberikan kepada peserta didik yang berdisiplin tinggi. Guru dalam menanamkan karakter disiplin menggunakan teknik external control melalui tindakan pengawasan yaitu dengan cara selalu mengawasi secara rutin kebersihan kuku dan kerapian rambut siswa supaya rapi. Jadi, guru memberikan hadiah kepada siswa yang selalu rajin mengerjakan pekerjaan rumah dengan memberikan pujian dan tepuk tangan yang tujuannya untuk memotivasi siswa agar lebih rajin lagi dalam belajar baik di sekolah maupun di rumah. Guru juga sudah menanamkan penanaman karakter disiplin melalui teknik external control yaitu berupa memberikan hadiah kepada siswa yang memiliki disiplin tinggi dalam mengerjakan pekerjaan rumah maupun tugas yang diberikan oleh guru. Hal tersebut sesuai dengan pendapat Noor, (2012), yang menyatakan bahwa mendisiplinkan peserta didik dengan teknik external control yaitu dengan memberikan ganjaran kepada siswa yang berdisiplin tinggi.

Guru dalam menanamkan karakter disiplin menggunakan teknik inner control yaitu berupa guru selalu menggunakan tutur kata sertabahasa yang baik dan sopan baik dalam penyampaian pembelajaran maupun dalam keseharian di dalam lingkungan sekolah. Hal tersebut sesuai dengan pendapat Noor, (2012), yang menyatakan bahwa mendisiplinkan peserta didik dengan teknik inner control yaitu dengan guru dituntut untuk menjadi teladan bagi peserta didik dalam hal kedisiplinan. Serta, guru dalam menanamkan disiplin menggunakan teknik inner control yaitu guru selalu meneladankan atau memberikan contohdengan cara selalu memakai seragam dengan rapi, baik dan sopanserta memakai seragam sesuai dengan jadwal yang sudah di tentukan sekolah. Hal tersebut sesuai dengan 
pendapat (Noor, 2012), yang menyatakan bahwa mendisiplinkan peserta didik dengan teknik inner control yaitu dengan guru dituntut untuk menjadi teladan bagi peserta didik dalam hal kedisiplinan.

Untuk menumbuhkan disiplin, siswa maupun guru harus menjalankan ketertiban dan kedisiplinan karena kesepakatan bersama. Sehingga guru akan berusaha untuk mendidik siswanya dengan baik yaitu dengan mengajarkan siswanya untuk menaati dan menjalankan aturan maupun kesepakatan yang sudah dibuat. Karena kesepakatan tersebut dibuat oleh dua pihak yaitu siswa dan guru. Sehingga guru dan siswa harus menjalankan kesepakatan tersebut. Hal tersebut sesuai dengan pendapat Noor, (2012), yang menyatakan bahwa mendisiplinkan peserta didik dengan teknik cooperatif control yaitu dengan guru bersama peserta didik membuat kontrak belajar yang berisi aturan yang harus ditaati bersama.

Penelitian yang dilaksanakan oleh Puji Rahayu dan Maisaroh (2008) hasil penelitian dapat ditarik kesimpulan bahwa guru berperan sebagai penyayang, model, dan mentor dalam membentuk karakter siswa. Sebagai penyayang, guru juga berperan sebagai pembimbing dan motivator. Sebagai model, guru juga berperan sebagai inspirator dan teladan, serta sebagai mentor guru juga berperan sebagai inisiator, evaluator, dan motivator. Begitu juga dengan penelitian yang dilaksankan oleh Setyawan et al., (2015). Hasil penilaian menunjukkan bahwa produk SSP dinyatakan layak dengan perincian silabus berkategori baik dengan skor 47, RPP skor 67, bahan ajar skor 65, LKPD skor 47 dan instrumen penilaian yang dikembangkan dinyatakan valid berkategori sangat baik, sedangkan media pembelajaran yang dikembangkan berkategori baik dengan skor 66. Hasil uji coba menunjukkan bahwa SSP yang dikembangkan dinyatakan memenuhi kriteria praktis dilihat dari penilaian guru skor 281 dan respon siswa skor 730. Pada uji coba lapangan didapatkan hasil untuk kelas kontrol rata-rata skor pretest 70,8 dan rata-rata skor posttest 80,8 . Sedangkan pada kelas eksperimen memperoleh skor rata-rata pretest 74,1 dan skor posttest 90,9. Peningkatan skor kelas kontrol sebesar 10 dan peningkatan kelas eksperimen sebesar 16,8. Pembelajaran dengan SSP yang dikembangkan mampu membangun karakter disiplin dan kreatif. Rata-rata hasil penilaian afektif siswa untuk karakter disiplin adalah $100 \%$ dan kreatif adalah 94\%. Penelitian yang dilaksanakan oleh Ansori (2020). Hasil penelitian membuktikan bahwa guru berperan penting dalam pembinaan disiplin siswa, sehingga siswa mentaati segala peraturan yang ditetapkan dan mencegah timbulnya problem-problem disiplin.

Berdasarkan penelitian yang sudah dilakukan diketahui bahwa hambatan yang terjadi dalam penanaman karakter disiplin siswa bukan hanya berasal dari siswa saja melainkan dari guru juga terdapat masalah ataupun hambatan. Kedatangan guru yang terkadang datang terlambat ke sekolah akan berakibat buruk bagi siswa. Karena siswa dalam tahap ini masih mencontoh apa yang guru berbuat. Sehingga seharusnya sebagai guru juga dituntut untuk menjadi teladan yang baik bagi siswanya. Pembelajaran yang tidak efektif didalam kelas juga berpengaruh terhadap disiplin waktu. Dimana penyampaian materi pembelajaran tidak tersampaikan secara maksimal. Selain itu juga, kurangnya perhatian, motivasi dan dukungan dari orangtua, serta pengaruh dari lingkungan akan membuat anak tidak disiplin. Anak sering terlambat, tugas atau PR sekolah tidak dikerjakan, dan lain sebagainya.

\section{Conclusion}

Berdasarkan hasil penelitian dan pembahasan dapat disimpulkan bahwa guru kelas sangat berperan (menentukan) dalam pembentukan karakter disiplin pada siswa dengan menggunakan 3 (tiga) teknik yaitu; 1) Teknik Inner Control yaitu keteladanan dalam segala aspek kehidupan sekolah sebagaimana dituangkan dalam peraturan Sekolah. 2) Teknik External Control yaitu menegakkan peraturan Sekolah dengan dua cara yaitu: Pertama memberikan hukuman yang bersifat mendidik kepada siswa yang melanggar peraturan (tidak 
disiplin). Kedua memberi pujian/hadiah/respon positif bagi siswa yang disiplin (tidak melanggar peraturan). 3) Teknik Cooperative Control yaitu mengadakan kerjasama yang diwujudkan dalam bentuk kontrak kerja yang berisi peraturan disiplin sekolah berupa tata tertib dan sanksinya bagi yang melanggarnya.

\section{References}

Abdullah, B., Radiansyah, R., \& Akbar, A. (2015). Pendidikan Karakter Di Madrasah Aliyah $\begin{array}{lllll}\text { Negeri (Man) } 2 \text { Banjarmasin. } & \text { Inferensi, } & \text { 9(2), } & \end{array}$ https://doi.org/10.18326/infs13.v9i2.537-560

Abu, S. N. (2014). Pembinaan Guru Oleh Kepala Sekolah dalam Pengelolaan Pembelajaran di Sekolah Dasar. Jurnal Administrasi Pendidikan, 2(1), 704-831.

Adibatin, A. (2016). Pendidikan Karakter Bangsa Berbasis Strategi Pembelajaran PAKEM Melalui Permainan Cincin di Jempol Tangan (Karya Inovasi Pembelajaran Sekolah Dasar). Scholaria: Jurnal Pendidikan Dan Kebudayaan, 6(1), 1. https://doi.org/10.24246/j.scholaria.2016.v6.i1.p1-18

Ansori, Y. Z. (2020). Penguatan karakter disiplin siswa melalui peranan guru di sekolah dasar. Jurnal Elementaria Edukasia, 3(1), 126-135.

Basri, B., \& Dwiningrum, N. R. (2020). Peran Ormawa dalam Membentuk Nilai-nilai Karakter di Dunia Industri (Studi Organisasi Kemahasiswaan di Politeknik Negeri Balikpapan). Al-Adabiya: Jurnal Kebudayaan Dan Keagamaan, 15(01), 139-160. https://doi.org/10.37680/adabiya.v15i01.273

Buntarti, R. S., \& Udjang, R. (2015). Kompensasi dan Disiplin Kerja pada Kinerja Karyawan dengan lama bekerja sebagai Variabel Kontrol. Jurnal Perilaku Dan Strategi Bisnis, $3(2), 1-9$.

Choli, I. (2019). Pembentukan Karakter Melalui Pendidikan Islam. Tahdzib Al-Akhlaq: Jurnal Pendidikan Islam, 2(2), 35-52. https://doi.org/10.34005/tahdzib.v2i2.511

Machfiroh, L., Desyanty, E. S., \& Rahmah, R. A. (2019). Pembentukan Karakter Disiplin Anak Usia Dini Melalui Metode Pembiasaan Di Tk Aisyiyah Bustanul Athfal 33 Kota Malang. Jurnal Pendidikan Nonformal V, XIV(1), 54-67. https://doi.org/http://dx.doi.org/10.17977/um041v14i1p54-67

Malik, A., \& Afandi, M. (2020). Peningkatan disiplin dan prestasi belajar pai menggunakan model quantum teaching kelas vii mts nu al ishlah binabaru. Jurnal Ilmiah Pendidikan Dasar, VII(1), 60-67. https://doi.org/https://doi.org/10.30659/pendas.7.1.60-67

Nasution, T. (2017). Konsep Dasar Pendidikan Kewarganegaraan Dalam Membangun Karakter Siswa. Jurnal Ilmu Sosial \& Budaya, 1(2), 1689-1699.

Noor, R. M. (2012). The Hidden Curriculum Membangun Karakter Melalui Kegiatan Ekstrakurikuler. Insan Mandiri.

Puji Rahayu; Maisaroh, S. (2008). Peran Guru Dalam Membentuk Karakter Siswa. Journal of Chemical Information and Modeling, 53(9), 287.

Setyawan, W. W., Mustadi, A., \& Yogyakarta, U. N. (2015). Pengembangan Ssp TematikIntegratif Untuk Membangun Karakter Disiplin Dan Kreatif Siswa Kelas I Sd. Jurnal Prima Edukasia, 3(1), 108-119. https://doi.org/10.21831/jpe.v3i1.4072

Sutiyono. (2013). Penerapan Pendidikan Budi Pekerti Sebagai Pembentukan Karakter Siswa Di Sekolah: Sebuah Fenomena Dan Realitas. Jurnal Pendidikan Karakter, O(3), 309320. https://doi.org/10.21831/jpk.v0i3.2753

Wuryandani, W., Maftuh, B., \& Budimansyah, D. (2014). Kata Kunci: 286-295. 